Ann. Biol. anim. Bioch. Biophys., 1977, 17 (6), 1005-1011.

\title{
Seasonal fluctuation of cholesterol in ovarian compartments of birds
}

\author{
par R. K. CHALANA, S. S. GURAYA
}

Department of Zoology, College of Basic Sciences and Humanities Punjob Agriculfural University, Punjab,

Ludhiana 141001 India.

Summary. A morphological, histochemical and biochemical study has been made of seasonal fluctuation in the cholesterol content of ovarian compartments in three species of birds (crow, Corvus splendens, common myna Acridotheres tristis and house sparrow, Passer domesticus). Histochemical localization of $\Delta^{5}-3 \beta-H S D H$ activity in different ovarian compartments has also been studied simultaneously. The pattern of seasonal fluctuation in the cholesterol content of the three bird species is similar. Cholesterol content is lowest in the reduced ovaries. It starts increasing in the prebreeding period, becomes maximum in the breeding period and decreases afterwards. The increasing level of cholesterol in the prebreeding period is mainly due to its storage in the stromal and thecal interstitial cells. The amount of cholesterol in the interstitial tissues is decreased during the breeding period and this is closely accompanied by an increase of their $\Delta^{5}-3 \beta-H S D H$ activity. Higher level of total ovarian cholesterol during the breeding period are mainly due to its accumulation in the cytoplasm of vitellogenic follicles. The functional significance of seasonal fluctuation in the cholesterol content of different ovarian compartments is discussed.

\section{Introduction.}

Seasonal fluctuation of the cholesterol content of steroidogenic tissues in the gonads of non-mammalian vertebrates is an important criterium of their functional status (Lofts et al., 1972 ; Lofts and Bern, 1972 ; Guraya, 1976a). Depending upon the physiological state of the ovary, the amount of its total cholesterol varies greatly throughout the reproductive cycle (Kern, 1972). This cholesterol is apparently present in different ovarian compartments including stroma, follicular wall and oocyte. The avian egg is known to contain a considerable amount of cholesterol (Turk and Barnett, 1971) which seems to be deposited during folliculogenesis. In addition to the developing oocytes, interstitial and thecal cells also accumulate cholesterol (Guraya, 1976a). Our knowledge about the seasonal fluctuation of cholesterol in different compartments of ovary in wild bird species is still very meagre (Lofts and Bern, 1972 ; Lofts and Murton, 1973 ; Guraya, 1976a). To fill this gap, the present study was initiated to determine the seasonal morphological, histochemical and biochemical changes in the cholesterol content of different ovarian compartments during the 
reproductive cycles of three wild bird species (common myna Acridotheres tristis ; crow Corvus splendens and house sparrow Passer domesticus). $\Delta^{5}-3 \beta$-hydroxysteroid dehydrogenase $\left(\Delta^{5}-3 \beta-H S D H\right)$ activity has also been studied with histochemical techniques in order to defermine the physiological significance of changes in cholesterol content.

\section{Material and methods.}

For the present investigation, the ovaries of three seasonally breeding birds, namely the crow (Corvus splendens), the common myna (Acridotheres tristis) and the house sparrow (Passer domesticus), were used throughout the year. The average ovarian weight for each month is given in table 1 . The phases of ovarian activity were determined by ovary shape, structure and weight as well as by the number and size of growing follicles.

\section{TABLE 1}

Seosonal fluctuation in mean ovarion weight (in $\mathrm{mg}$ ) and total cholesterol content $(\mathrm{mg} / \mathrm{g}$ wet weight of the tissue) in the myno, crow and house sparrow

\begin{tabular}{|c|c|c|c|c|c|c|c|c|c|}
\hline \multirow[b]{2}{*}{ Month } & \multicolumn{3}{|c|}{ Myna } & \multicolumn{3}{|c|}{ Crow } & \multicolumn{3}{|c|}{ House sparrow } \\
\hline & Weight & $\begin{array}{l}\text { Total } \\
\text { choles- } \\
\text { terol }\end{array}$ & & Weight & $\begin{array}{l}\text { Total } \\
\text { choles } \\
\text { terol }\end{array}$ & & Weight & $\begin{array}{l}\text { Total } \\
\text { choles- } \\
\text { terol }\end{array}$ & \\
\hline 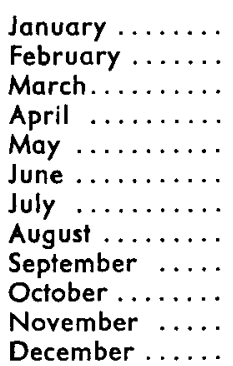 & $\begin{array}{l}27.6 \\
30.4 \\
51.1 \\
75 \\
208 \\
282.5 \\
255 \\
75 \\
50 \\
41.2 \\
28 \\
22\end{array}$ & $\begin{array}{r}5.08 \\
7.80 \\
7.52 \\
12.02 \\
12.09 \\
15.52 \\
14.55 \\
7.62 \\
7.95 \\
6.84 \\
6.25 \\
5.25\end{array}$ & $\begin{array}{l}Z \\
Z \\
5.0^{*} \\
5.25^{*} \\
5.32^{*} \\
- \\
- \\
- \\
-\end{array}$ & $\begin{array}{l}21 \\
31 \\
50.00 \\
86.5 \\
79.5 \\
383.3 \\
349 \\
315.6 \\
142.5 \\
50 \\
22 \\
19\end{array}$ & $\begin{array}{r}2.50 \\
2.58 \\
7.22 \\
11.30 \\
10.52 \\
12.11 \\
12.00 \\
12.82 \\
9.67 \\
2.05 \\
2.20 \\
2.18\end{array}$ & $\begin{array}{l}\bar{Z} \\
\overline{-} \\
\overline{-} \\
2.63^{*} \\
2.55^{*} \\
2.65^{*} \\
- \\
- \\
-\end{array}$ & $\begin{array}{r}18.42 \\
31.87 \\
39.81 \\
156.56 \\
155.71 \\
142.31 \\
185.50 \\
21.54 \\
31.00 \\
26.17 \\
14.83 \\
14.00\end{array}$ & $\begin{array}{r}7.50 \\
7.80 \\
12.50 \\
14.34 \\
16.00 \\
18.82 \\
12.65 \\
12.00 \\
15.90 \\
12.80 \\
0.47 \\
6.47\end{array}$ & $\begin{array}{l}\bar{Z} \\
\bar{Z} \\
5.62 * \\
5.62 * \\
6.52 * \\
- \\
= \\
- \\
-\end{array}$ \\
\hline
\end{tabular}

* Cholesterol content of the ovarian tissue after removal of vitellogenic follicle.

For estimation of cholesterol, the weighed ovarian material was homogenized in ethylaicohol: diethylether $(3: 1 \mathrm{v} / \mathrm{v})$. The supernatant was evaporated and the residue was dissolved in chloroform. The colour was developed with acetic anhydride and concentrated $\mathrm{H}_{2} \mathrm{SO}_{4}$ (Cook, 1958). The colour intensity was measured with spectronic 20 at $620 \mathrm{~nm}$. The amount of cholesterol was calculated in $\mathrm{mg} / \mathrm{g}$ of the wet weight of ovarian tissue. In order to analyze the cholesterol content of different ovarian compartments, the growing follicles in the breeding period were isolated from the ovarian stroma. These follicles in their successive stages of growth, and the ovarian stroma were weighed and analyzed separately for cholesterol. 
The histochemical localization of cholesterol in different ovarian compartments was carried out in frozen sections of the ovarian material fixed in calcium-formol and treated with Schultz test (Pearse, 1968). $\Delta^{5}-3 \beta-H S D H$ was localised in frozen sections of the material fixed in cold buffered formalin (0-4 ${ }^{\circ} \mathrm{C}$ ) after Thompson (1966), using pregnenolone as a substrate. Simultaneous controls were carried out for both cholesterol and $\Delta^{5}-3 \beta-H S D H$.

\section{Results.}

Phases of ovarian activity during reproductive cycle. The three bird species used for the present study show definite breeding periods. Crow and myna exhibit a single breeding period which extends from June to August and May to July respectively. In contrast, the house sparrow has two breeding periods, i. e. April to July and September to October. During the breeding periods, the ovary shows a graded series of yellow vitellogenic follicles; 3-5 large follicles are usually seen hanging from the ovarian surface. In winter months (November-February), the ovarian size in all the bird species used is greatly reduced. At this stage, the ovary forms a compact structure containing only the small primordial and early previtellogenic follicles. The reduced ovary is, therefore, considered inactive or quiescent. In spring (March-April), the ovaries begin to increase in size and weight due to follicular growth. This period is distinguished here as a preparation phase for breeding, and hence is called the prebreeding period. Corresponding to the these gross annual ovary changes, the stromal and thecal interstitial tissues also show conspicuous fluctuations in amount and distribution as described in previous papers (Guraya and Chalana, 1976 ; Chalana and Guraya, 1977). These studies have shown that the interstitial tissue is extensively developed during the prebreeding and breeding periods. It regresses during the nonbreeding period.

Total ovarian cholesterol. Annual changes in the total ovarian cholesterol in the crow, myna and house sparrow are summarized in table 1 . The amount of cholesterol is low in the reduced ovaries. It begins to increase during the prebreeding period, becomes maximum during the breeding period and then decreases during the postbreeding period. The patterns of cholesterol fluctuation are basically similar in the bird species used. The house sparrow exhibits two breeding periods but the amount of cholesterol remains almost constant from the onset of the first breeding period up to the end of the second one. Its ovary consists mainly of large-sized previtellogenic follicles during the intermittent period of two breeding seasons. This phase can be considered as the prebreeding period for the amount of ovarian cholesterol during this period basically remains the same as that observed in the prebrefding period of the first breeding season.

After the removal of yellow follicles during the breeding period, the amount of ovarian cholesterol is greatly decreased. It becomes less than the ovarian cholesterol of prebreeding and reduced ovaries. These observations indicate that during the breeding period, the major part of the total ovarian cholesterol is present in the yellow follicles. 
Cholesterol contents of isolated follicles. The cholesterol content of isolated previtellogenic and vitellogenic follicles is given in table 2 . As compared to early small follicles, the cholesterol content of large previtellogenic follicles is lower. The amount of total ovarian cholesterol increases progressively in large yellow follicles.

TABLE 2

Cholesterol content $(\mathrm{mg} / \mathrm{g}$ wet weight of the tissue) of follicles of varying diameter (in $\mathrm{mm}$ ) during the breeding period.

\begin{tabular}{|c|c|c|c|c|c|c|c|c|}
\hline \multirow[b]{2}{*}{ Bird } & \multicolumn{2}{|c|}{$\begin{array}{l}\text { Late } \\
\text { vitellogenic }\end{array}$} & \multicolumn{2}{|c|}{$\begin{array}{c}\text { Early } \\
\text { vitellogenic }\end{array}$} & \multicolumn{2}{|c|}{$\begin{array}{c}\text { Late } \\
\text { previtellogenic }\end{array}$} & \multicolumn{2}{|c|}{$\begin{array}{c}\text { Early } \\
\text { previtellogenic }\end{array}$} \\
\hline & $\begin{array}{c}\text { Mean } \\
\text { diameter }\end{array}$ & $\begin{array}{l}\text { Total } \\
\text { choles- } \\
\text { terol }\end{array}$ & $\begin{array}{c}\text { Mean } \\
\text { diameter }\end{array}$ & $\begin{array}{l}\text { Total } \\
\text { choles- } \\
\text { terol }\end{array}$ & $\begin{array}{l}\text { Mean } \\
\text { diameter }\end{array}$ & $\begin{array}{l}\text { Total } \\
\text { choles- } \\
\text { terol }\end{array}$ & $\begin{array}{c}\text { Mean } \\
\text { diameter }\end{array}$ & $\begin{array}{l}\text { Total } \\
\text { choles- } \\
\text { terol }\end{array}$ \\
\hline $\begin{array}{l}\text { Crow ........ } \\
\text { Common myna } \\
\text { House sparrow }\end{array}$ & $\begin{array}{r}12.0 \\
11.0 \\
8.0\end{array}$ & $\begin{array}{r}9.15 \\
11.64 \\
16.36\end{array}$ & $\begin{array}{l}5.0 \\
6.0 \\
7.0\end{array}$ & $\begin{array}{r}2.62 \\
2.56 \\
10.20\end{array}$ & $\begin{array}{l}3.0 \\
3.0 \\
2.0\end{array}$ & $\begin{array}{l}2.28 \\
2.62 \\
3.72\end{array}$ & $\begin{array}{l}0.8 \\
0.8 \\
0.46\end{array}$ & $\begin{array}{l}6.25 \\
7.08 \\
8.96\end{array}$ \\
\hline
\end{tabular}

Histochemical localization of cholesterol and $\Delta^{5}-3 \beta-H S D H$. The cholesterol is localized in the stromal and thecal interstitial cells and oocytes throughout the reproductive cycle. The number of interstitial cells is less in the reduced ovaries than in the enlarged ovaries of prebreeding and breeding periods (Guraya and Chalana, 1976 ; Chalana and Guraya, 1977), but the interstitial cells show accumulation of cholesterol-positive lipid droplets. Their weak reaction for $\Delta^{5}-3 \beta-H S D H$ activity indicates a decreased rate of the conversion of cholesterol into steroid hormones. The number of interstitial cells begins to increase during the prebreeding period, but the Schultz-positive reaction for cholesterol is not much altered. In contrast, it decreases during the breeding period, indicating that cholesterol depletion in the interstitial cells at this stage is simultaneous with a considerably increased $\Delta^{5}-3 \beta-\mathrm{HSDH}$ activity. The follicular wall of early previtellogenic follicles shows some scattered cholesterol-positive thecal cells ; their number increases in large previtellogenic follicles. Meanwhile, their cholesterol content also increases. With the onset of vitellogenesis, the cholesterol content of thecal cells decreases. This is closely accompanied by the increase of $\Delta^{5}-3 \beta-H S D H$ activity. The ooplasm of primordial follicles shows cholesterol-positive lipid droplets throughout the reproductive cycle, which decrease with the growth of previtellogenic follicles. But heavy deposition of cholesterol occurs in the vitellogenic follicles. The activity of $\Delta^{5}-3 \beta-H S D H$ is not seen in the ooplasm of growing oocytes.

\section{Discussion.}

This study has revealed that corresponding to the morphological changes of ovaries during the reproductive cycles of three seasonally breeding birds, their cholesterol shows conspicuous fluctuations. In the reduced ovaries, the amount of cholesterol is low. It begins to increase during the prebreeding period, becomes maximum 
during the breeding period and then decreases in the postbreeding period. In contrast to the present observations, the previous studies on white-crowned sparrow have shown that the cholesterol content is maximum in the inactive phase and depleted one month before the oviduct and brood patch are fully developed (Kern, 1972). The histochemical observations have revealed that the cholesterol demonstrated biochemically in the reduced ovaries is localized in the interstitial tissue, and primordial and early previtellogenic oocytes. But the number of interstitial cells is relatively less in the reduced ovaries than in those of the prebreeding and breeding periods (Guraya and Chalana, 1976 ; Chalana and Guraya, 1977). The number of interstitial cells and oocyte size begin to increase during the prebreeding period. The increased cholesterol level during the prebreeding period can be correlated to its deposition in the greatly developed interstitial and thecal gland cells of growing and atretic follicles; follicular atresia is very extensive during the prebreeding period. Since cholesterol is a precursor of steroid hormones (Lofts and Bern, 1972), its prior deposition in interstitial tissues is necessary to the secretion of increasing amounts of steroids during the breeding period. The conspicuous decrease of cholesterol content in the interstitial cells with simultaneous increase of $\Delta^{5}-3 \beta-H S D H$ activity during the breeding period confirms its utilisation for the formation of steroids. The interstitial cells in the avian ovary have been regarded as the source of androgen (Taber, 1951 ; Marshall and Coombs, 1957 ; Woods and Domm, 1966 ; Saylor ef al., 1970 ; Kern, 1972 ; Lofts and Murton, 1973 ; Guraya, 1976a, b). Therefore, it is reasonable to conclude that the cholesterol depletion in the interstitial cells during the breeding periods of the crow, myna and house sparrow must be closely related to the increasing secretion of androgens required for heightened breeding activities (Lofts, 1975).

In comparison to the primordial and early previtellogenic follicles, the large previtellogenic follicles developed during the prebreeding period show relatively less cholesterol in their ooplasm as demonstrated by the correlative histochemical and biochemical techniques. Cholesterol depletion in the ooplasm of previtellogenic follicles cannot be related to steroid synthesis, as $\Delta^{5}-3 \beta-\mathrm{HSDH}$ activity is not seen at this site. However, it appears that their cholesterol content demonstrated with biochemical techniques is mainly present in the thecal cells as revealed by the histochemical techniques.

The higher levels of ovarian cholesterol during the breeding period are mainly due to its deposition in the vitellogenic follicles as the cholesterol content of interstitial and thecal cells decreases considerably at this phase of heightened reproductive activity. The accumulation of abundant cholesterol in the vitellogenic follicle is further supported by the fact that the ovaries without such follicles show very little cholesterol ; cholesterol of vitellogenic follicles is mainly localized in the yolk (Turk and Barnett, 1971). Vitellogenic follicles are known to be the source of œstrogens in birds (Kumagai and Homma, 1974). Mobilization of cholesterol-positive lipid droplets correlated to intense $\Delta^{5}-3 \beta$-HSDH activity in the thecal cells suggests that they form the steroidsynthesizing cellular site in the vitellogenic follicles. These œstrogens are, therefore, secreted by the thecal cells and not by the ooplasm of the vitellogenic follicles. Increased œstrogen levels during the breeding period are known to stimulate hepatic synthesis of yolk (Kumagai and Homma, 1974) which is then transported to the vitellogenic follicles. 
The marked decrease in the total ovarian cholesterol during the postbreeding period can be attributed to the absence of vitellogenic follicles and decrease in the number of cholesterol-rich interstitial cells. Cholesterol of the reduced ovaries is mainly present in the sparsely distributed interstitial cells as determined by the histochemical techniques. The accumulation of cholesterol in the interstitial cells during the postbreeding period indicates a regression in their steroidogenic activity as they subsequently enter the inactive phase.

Reçu en mars 1977.

Accepté en juin 1977.

Résumé. Une étude morphologique, hixtologique et biochimique a été effectuée sur les variations saisonnières de la teneur en cholestérol des compartiments ovariens de trois espèces d'oiseau (Corvus splendens, Acridotheres tristis, Passer domesticus). La localisation histochimique de la $\Delta^{5}-3 \beta$-ol SDH a été également recherchée.

Le profil des variations saisonnières du contenu en cholestérol est semblable pour les trois espèces. La teneur est faible dans les ovaires au repos. Elle commence à s'élever juste avant la période de reproduction, période pendant laquelle elle est maximum ; puis elle décroît. L'élévation avant la période de reproduction est due principalement à un stockage dans les celfules interstitielles du stroma et les cellules thécales. Pendant la période de reproduction, dans les cellules du stroma la teneur a diminué, tandis que l'activité $\Delta^{5}-3 \beta$ ol SDH s'est élevée. Les hautes teneurs en cholestérol de l'ovaire pendant la période de reproduction résultent d'une accumulation dans les ovocytes ayant formé leur vitellus. La signification fonctionnelle des variations saisonnières du contenu en cholestérol des différents compartiments de l'ovaire est discutée.

\section{References}

CHALANA R. K., GURAYA S. S., 1977. Seasonal fluctuations and histochemical characteristics of the interstitial cells in the ovary of crow and myna. Gen. Comp. Endocrinol. (In press).

COOK R. P., 1958. Cholesterol chemistry, biochemistry and pathology. Acad. Press, New York.

GURAYA S. S., 1976a. Recent advances in the morphology, histochemistry and biochemistry of steroid-synthesizing cellular sites in the nonmammalian vertebrate ovary. Int. Rev. Cytol., 44, $365-404$.

GURAYA S. S., 1976b. Morphological and histochemical observations on the follicular atresia and interstitial gland tissue in the columbid ovary. Gen. Comp. Endocrinol., 30, 534-538.

GURAYA S. S., CHALANA R. K., 1976. Histochemical observations on the seasonal fluctuations in the follicular atresia and interstitial gland tissue in the house sparrow ovary. Poult. Sci., 55, $1881-1885$.

KERN M. D., 1972. Seasonal changes in the reproductive systems of female white crowned sparrow Zonotrichia leucophrys gambelli in captivity and in the field I. The ovary. Z. Zellforsch. mikrosk. Anat., 126, 297-319.

KUMAGAI S., HOMMA K., 1974. High estrogen production of the medium-sized follicles during follicular growth and ovulation in the laying quail. Endocrin. jap., 21, 349-354.

LOFTS B., BERN H. A., 1972. The functional morphology of steroidogenic tissue, 37-117. In : IDLER D. R. Steroids in Nonmammalian Vertebrates. Acad. Press, New York.

LOFTS B., WELLEN J. J., BENRAAD Th. J., 1972. Seasonal changes in endocrine organs of the male common frog Rana temporario III. The gonads and cholesterol cycles. Gen. Comp. Endocrinol., 18, 344-363.

LOFTS B., MURTON R. K., 1973. Reproduction in birds, 1-107. In : FARNER D. S., KING J. R., Avian Biology. Acad. Press, N. Y., London.

LOFTS B., 1975. Environmental control of reproduction, In : PEAKER M., Avion Physiology. Symp. Zool. Soc. Lond., no 35, 177-198. Acad. Press, N. Y., London. 
MARSHALL A. J., COOMBS J. A., 1957. The interaction of environmental internal and behavioural factors in rook, Corvus fruigilegus. Proc. Zool. Soc. London, 128, 545-589.

PEARSE A. G. E., 1968. Histochemistry, theoretical and applied, Churchill London.

SAYLOR A., DOWD A. J., WOLFSON A., 1970. Influence of photoperiod on the location of $3 \beta$ hydroxysteroid dehydrogenase in the ovaries of maturing Japanese quail. Gen. Comp. Endocrinol., 15, 20-30.

TABER E., 1951. Androgen secretion in the fowl. Endocrinology, 48, 6-16.

THOMPSON S. W., 1966. Selected histochemical and histopathological methods. Ch. C. Thomas Publ., Springfield and Illinois.

TURK D. E., BARNETT B. D., 1971. Cholesterol content of market eggs. Poult. Sci., 50, 1303-1306.

WOODS J. E., DOMM L. V., 1966. A histochemical identification of the androgen producing cells in the gonads of domestic fowl and albino rat. Gen. Comp. Endocrinol., 7, 559-570. 